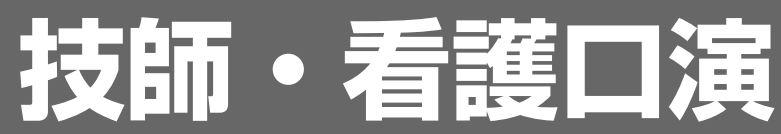





\section{技師 01-1}

脳動脈瘤カットによる瘤の発症と血流に関する検討

済生会和歌山病院 放射線科 ${ }^{1}$

済生会和歌山病院 脳神経外科 ${ }^{2)}$

イービーエム株式会社 血流解析事業部 ${ }^{3)}$

引網雄介 ${ }^{1)}$ 山家弘雄 ${ }^{2)}$ 小森 崇 ${ }^{1)}$ 山崎直也 ${ }^{1)}$ 宇野好人 ${ }^{1)}$

Hikiami Yuusuke

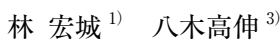

【目的】脳動脈瘤の発症は血流と関連していると考えられているが, どのような血流が瘤の発症を誘発するのかは不明であり，更なる理 解を必要としている. 脳動脈瘤を発症した症例に対して, 瘤をコン ピュー夕上で切除し発症時の血管形状を再現することで, 発症部に 特異的な血流の存在を明らかにすることを目的とする.【方法】 カーブの外弯側に発症した side wall type の動脈瘤を対象とした. 血流を数值流体力学 (CFD) により拍動流で計算を行った．解析 には ziostation 2 (ザイオソフト株式会社) と hemoscope 2014 (イー ビーエム株式会社）を使用した。結果を，血管壁圧力（WP），壁 面せん断応力の大きさ (WSSm), 壁面せん断応力べクトルの方向 (WSSv), 時間変動（WSSvv）から評価した. WSSv は平行, 合流, 回転, 発散の形態から評価した。【成績】内頚動脈瘤 4 例と前大脳 動脈瘤 1 例の計 5 例（男性 2 例，女性 3 例，平均年齢 73.2 歳）に ついて検討した。すへてて症例の解析に成功した５例とも動脈瘤 があった部分の付近に血流の衝突をみとめ, WP は局所的に増大し ていた. WSSv は発散する傾向をみとめた．血流衝突部において, WSSm が低下し，その周囲はWSSm が増大しており，壁面せん断 応力の勾配が高い特徴をみとめた. WSSvvは著明に変動してお り, 瘤近傍に 200 度以上の高い不安定性を全例にみとめた。WP の 増大部や，WSSvの発散部は，瘤近傍には存在したが，必ずしも瘤 の中心部というわけではなかった.【結論】今回の side wall type の動脈瘤では, 瘤をカットした部分において, 瘤近傍に血流の衝突 を確認した．これは血流の衝突による壁面せん断応力べクトルの発 散や変動が瘤の発症に関与している可能性を示唆している.

\section{技師 $01-3$}

非造影 3D TOF MRA における脳動脈瘤ステント併用コイル 塞栓術後の血流描出改善の検討

\section{特定医療法人医翔会札幌白石記念病院 放射線部 ${ }^{1)}$} 特定医療法人医翔会札幌白石記念病院 脳血管内治療センター ${ }^{2)}$ 木村紀行 ${ }^{1)}$ 金成宏明 ${ }^{1)}$ 平田秀喜 ${ }^{1)}$ 小山内秀幸 ${ }^{1)}$ 恩田敏之 ${ }^{2)}$ Kimura Noriyuki

米増保之 ${ }^{2)}$ 高橋 明 $^{2)}$ 野中 雅 $^{2)}$

【目的】 2010 年の認可以降，サイズの大きな脳動脈瘤や wide neck 型脳動脈瘤に対する治療としてステント併用によるコイル塞栓術を おこなうケースが増えている。 しかしながら，ステントの材質が ニッケルーチタン合金であるナイチノールであるため, 特に closed cell type のステントに対する MRA での治療後血管評価が困難で あった。これについて造影 MRA ではステント留置血管が描出され るという報告があるが, 非造影 3 D TOF MRA での描出の試みに 関する報告は少ない，よって我々はパラメータを金属の影響が減少 するよう最適化することでステント留置血管の描出が改善されるか を検討した.【方法】 closed cell type のステントを封入した模擬血 管に, グリセリン溶液を定速注入し, 3 D TOF MRA を撮像した. このとき金属の影響を考慮し TE を短くすることが有効かを検討し た. 次に得られたTEにおいて flip angleを変化させ，ステント内 の in flowの信号值が上昇するかを検討した．使用装置は GE healthcare 3.0 T MRI 装置 Signa HDxt ver. 23 である. 固定パラ メーターは TR $25 \mathrm{~ms}$, slice thickness $0.4 \mathrm{~mm}$ (ZIP 2), matrix $320 \times 224$, FOV $21 \mathrm{~cm}$, band width $135 \mathrm{kHz}$. 【結果・結論】 TE を短くすることによりステント内の in flow 信号のばらつきの改善 が確認できた. また flip angleに関しては, angleを大きくしてい くことでステント内の信号が上昇することが確認された. flip angle 30 度以上ではほぼプラトーになることから, 設定しうる最も 短い $\mathrm{TE}=1.4 \mathrm{~ms}$ でかつ flip angle 30 度程度に設定することで非 造影 3 D TOF MRA において closed cell type のステント内の血流 描出の改善が図れた.
技師01-2

位相コントラストMRI による脳血流量と血管径の関連性

医療法人社団 KNI 北原国際病院 検査放射線科 ${ }^{1)}$

早稲田大学先端生命医科学センターTWIns ${ }^{2)}$

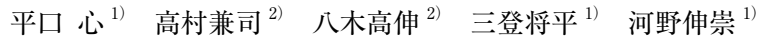

Hiraguchi Shin

林 祥史 ${ }^{1)}$ 祖母井龍 ${ }^{1)}$ 吉田浩貴 ${ }^{1)}$ 西谷和敏 ${ }^{1)}$ 岡田義文 ${ }^{1)}$ 百瀬義雄 ${ }^{1)}$ 北原茂実 ${ }^{1)}$

【背景・目的】数值流体力学 (CFD) による脳動脈瘤の研究が注目

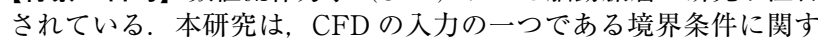
る. 境界条件は，1）実測法，2）統計法，3）推定法などの方式に より決められる. 本研究は推定法に関する. 壁面せん断応力 （WSS）が一定になるように血管径は調節されているとする報告が ある. 一方で, 当該知見をヒトの脳動脈で検証したデー夕はない. そこで, 脳動脈における血流量と血管径の関連性を検討した。【方 法】健常ボランティア 5 例に対して位相コントラスト MRI（PCMRI）を用い内澒動脈, 中大脳動脈, 前大脳動脈, 後交通動脈, 後 大脳動脈, 上小脳動脈, 脳底動脈の流量及び血管径を計測した。 ハーゲンポアズイユ理論にもとづいて血流量と血管径の関係を検討 した.【結果】全ての症例において血流量と血管径には正の相関を 確認した. 内頸動脈以外の場合, 相関係数 $\mathrm{R} 2$ が 0.75 以上と強い 線形関係を得られた。すなわち, 流量と直径の 3 乗は比例すること になる. 一方, 内頝動脈では, 他血管からの冕脱を認めた. 内䅡動 脈では慣性力が強く流れが偏心するためと考えられた。【結語】脳 動脈の血流量と血管径は相関しており，WSSの一定説を裏付ける 結果を得た，今後は，内澒動脈の更なる検討および患者を考慮した 研究が必要となる。

\section{技師01-4}

64 列 MDCT を用いた硬膜動静脈瘻における shunt point 描 出を目的とした Dynamic CTA の有用性

聖マリアンナ医科大学 横浜市西部病院 画像診断部 ${ }^{1)}$ 聖マリアンナ医科大学 横浜市西部病院 脳神経外科 ${ }^{2)}$

木林由布 ${ }^{1)}$ 青柳博樹 ${ }^{1)}$ 小野寺英孝 ${ }^{2)}$ 庄司善一 ${ }^{1)}$

Kibayashi Yu

榊原陽太郎 $^{2)}$ 中山兼二 ${ }^{1)}$

【目的】硬膜動静脈㾇における血管内治療は複数にわたる fistulaの 正確な把握が必要である. 通常は血管撮影で選択的に動脈造影を行 い評価するが, 複数の feeder が存在する場合は各々の血管からの 造影検査が必要となる。一方で, 経静脈的に造影剂を注入する CT 検査では一度の検査で複数の feeder および骨の情報を得ることが できる.さらにDynamic 撮影を行うことで血行動態の評価が可能 となり正確な shunt pointの把握ができ治療に有用である. 今回, 横・S 状静脈洞部硬膜動静脈瘦の患者に対して, 64 列 MDCTを用 いて詳細な fistula 描出を目的としたDynamic CTAを施行したの で報告する。【方法】 64 列 MDCT では $32 \mathrm{~mm}$ の幅で Dynamic 撮 影が行える. 来院時の CTA と血管撮影の情報を参考に, $32 \mathrm{~mm}$ の 幅に目的部位が含まれるようにポジショニングを行った。被ばくを 考慮し撮影範囲から水晶体は外して管電圧は通常の $120 \mathrm{KV}$ から

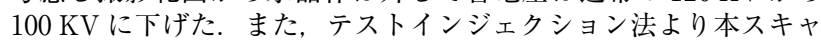
ンの撮影時間を決定し不必要な照射時間を減らした。【使用機器】 東芝 Aquilion CX, 根本杏林堂 DUALSHOT GX, アミン Ziostation 2【結果・考察】Dynamic CTAによりdural vein や parasinusなどの異常血管が収束する shunt point の描出を行うこ とができた. Dynamic CTA で得られた画像はワークステーション で様々な画像表示法を用いて任意の角度で表示することができ，か つ, 動画での観察により造影剤の流出入を観察できるため, shunt point の把握に有利であると考える。この情報に基づき血管内治療 を行うことは安全かつ正確な手技を可能とし，さらに手技時間の短 縮やコイルの節約につながるため, 硬膜動静脈瘦における Dynamic CTA は有用であると考える. 


\section{技師 $01-5$}

低線量 4 D-CTAngiography（4 D-CTA）の血管描出改善の 試み

札幌医科大学附属病院 放射線部 ${ }^{11}$

札幌医科大学 医学部脳神経外科学講座 2)

平野 透 $^{1)}$ 本間修一 $^{1)}$ 三角昌吾 ${ }^{1)}$ 飯星智史 ${ }^{2)}$ 宮田 圭 $^{2)}$ Hirano Toru

長濱宏史 ${ }^{1)}$ 櫻井佑樹 ${ }^{1)}$ 鈴木淳平 $^{1)}$ 小田原好宏 ${ }^{1}$

【目的】低線量 4 D-CTA のデータから高精細な三次元画像作成する ためには，時系列に再構成された元デー夕を加算処理 (Stack) す ることでノイズの少ない画像を得ることができる. しかし, stack 処理は単純加算平均処理の為に血管内 CT 值が平均化されることに より高い CT 值での三次元画像が作成出来ないことがある。 そこで ノイズの低減を維持しながら時系列内の血管内最大 CT 值を確保で きる新しい加算処理 (Time MIP) 考案した。本研究は Time MIP の概要と利点さらに問題点について報告する.【方法】CT 装置は Aquilion ONE (東芝社製) を使用した。自作ファントム及び臨床 症例による Dynamic Volume scanによって得られた時系列デー夕 に対し, Stack 処理及び Time MIP 処理を行い血管内 CT 值や画像 ノイズ等を評価した。【結果】 Time MIP 処理では時系列内の最大 CT 值を反映した画像になるため三次元画像作成において stack 処 理に比べて微細血管描出の改善が期待された，しかし，画像ノイズ は stack 処理に比べてやや高い傾向にあり，高分解能画像再構成関 数になるほどノイズが多くなり, ソフトの改善または画像再構成関 数の選択を考慮する必要が現状ではある。

\section{技師01-7}

\section{ステント併用脳動脈瘤コイル塞栓術後評価における Dual- Energy CT の有用性 \\ 特定医療法人医翔会 札幌白石記念病院 放射線部 ${ }^{1)}$ 特定医療法人医翔会 札幌白石記念病院 脳血管内治療センター ${ }^{2)}$ 笹森大輔 ${ }^{1)}$ 茅野伸吾 $^{1)}$ 入井亮介 ${ }^{1)}$ 山下智文 ${ }^{1)}$ 赤川真人 ${ }^{1)}$ Sasamori Daisuke \\ 恩田敏之 ${ }^{2)}$ 米増保之 ${ }^{2)}$ 高橋 明 ${ }^{2)}$ 野中 雅 ${ }^{2)}$}

【背景】ステント併用脳動脈瘤コイル塞栓術後評価に関して，DSA による血管撮影や造影 MRA が有用との報告がある. Dual-Energy CT はデバイスに応じたエネルギー選択が可能で, 術後評価の要点 であるステント形状や malapposition などの評価を行える可能性が ある。【方法】GE 社製 Dual-Energy CT (DECT) Discovery CT 750 HD において, Enterprise VRD を撮像し, $40 \mathrm{keV}$ から $140 \mathrm{keV}$ の Monochromatic Image（MI）を再構成した。 ステント ストラッドの CT 值を ImageJ にて計測し, Single-Energy CT （SECT）と比較した. また, Maximum intensity projection（MIP） 画像にて視覚評価を行った。 ステント描出に最適なエネルギーを選 択し，臨床例への適応を行った。【結果】ステントストラットの CT 值は $40 \mathrm{keV}$ の MI にて最大值を示し, MIP 画像も最も明瞭に 描出した。臨床例においてステント描出に最適な MI のエネルギー を $40 \mathrm{keV}$ と選択して, 術後評価に適した画像を作成することが可 能であった.【考察】Dual-Energy CTによるステントストラッド

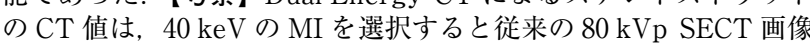
と比して, $250 \mathrm{HU}$ 程度高い值を示した。 これにより, SECTにて 術後評価困難であったステント形状や malapposition などの評価が 行えるとともに, stent thrombosis の検出に有効に利用可能と考え る.【結論】ステント併用脳動脈瘤コイル塞栓術後評価における Dual-Energy CT の有用性が示唆された.

\section{技師 01-6}

金属アーチファクト低減処理ソフトを用いた脳動脈瘤コイル塞 栓術後患者の 3 D-CTA の基礎的検討

富山県済生会富山病院 放射線技術科 ${ }^{1)}$

富山県済生会富山病院 脳卒中センター・脳神経外科 ${ }^{2)}$

富山大学 医学部 脳神経外科 ${ }^{3}$

高橋亮次 ${ }^{1)}$ 松井幹夫 ${ }^{1)}$ 石崎宗一郎 ${ }^{1)}$ 野崎春奈 ${ }^{1)}$ 上田周平 ${ }^{1)}$

Takahashi Ryoji

和田望未 ${ }^{1)}$ 前多尚人 ${ }^{1)}$ 久保道也 ${ }^{2)}$ 岡本宗司 ${ }^{21}$ 堀江幸男 ${ }^{2)}$

桑山直也 ${ }^{3)}$ 黑田 敏 ${ }^{3}$

【目的】脳動脈瘤コイル塞栓術後患者の 3 D-CTA 検査では動脈瘤の ネック近傍の親血管はコイルの金属アーチファクトにより今まで描 出困難であった，当院で新たに逐次近似再構成を応用した単一エネ ルギーによる金属アーチファクト低減処理（以下 SEMAR）を搭載 した東芝社製 Aquilion ONEが導入された. SEMARを使用してコ イルのアーチファクト低減について検討する.【方法】 20 倍希釈造 影剂で満たした直径 $5 \mathrm{~mm}$ のストローに直径約 $10 \mathrm{~mm}$ のコイル塊 を巻き付けた自作ファントムを用いて，撮影条件（管電圧，回転速 度, 管電流, ファントム角度), 再構成関数を変化させて撮影した。 各条件の SEMAR ON/OFF でのストロー内のプロファイルカーブ をとり, CT 值の変化をカーブ下面積を用いて評価した.【結果】 どの条件においても SEMARを使用することによってコイルによ るアーチファクトは低減した. 特に CT 值がマイナス方向にシフト するアーチファクトについては大きく低減した。【結論】SEMAR を使用することで脳動脈瘤コイル塞栓術後患者の 3 D-CTA 検査の コイル近傍の血管が描出される可能性が示唆された.

\section{技師 O2-1}

頚動脈 3 D-RA における血流量を考慮した希釈造影法の基礎的 検討

砂川市立病院 放射線科 ${ }^{1)}$

砂川市立病院 検查科 ${ }^{2)}$

砂川市立病院 脳神経外科 ${ }^{3)}$

増子陽洋 ${ }^{1)}$ 菊池孝紘 ${ }^{1)}$ 三国孝平 ${ }^{1)}$ 松原健一 ${ }^{1)}$ 阿部憲司 ${ }^{1)}$

Masuko Akihiro

木本謙介 ${ }^{1)}$ 吉野伸昭 ${ }^{2)}$ 鵜飼 亮 $^{3)}$ 関 隆史 ${ }^{3)}$

【目的】 3 D-Rotation Angiography（以下，3 D-RA）において，近 年では検查目的に合わせた希釈造影法の検討が行われている. 当院 にて，文献などを参考に最適とされる希釈造影法にて頚動脈 3 D-RA を施行したところ，期待通りの結果が得られない事例が存 在した，原因として，澒動脈の拍動や血流動態などが造影能に影響 したのではないかと考えられ，実際の臨床においては，そのような 影響を加味した希䣋造影法が必要と思われる。今回我々は，造影効 果に影響を与える因子として血流量に着目し, 頚動脈 3 D-RA にお ける希橎造影法について検討した.【方法】内腔が直径 $4.7 \mathrm{~mm}$ と $9 \mathrm{~mm}$ の円柱型模擬血管ファントムを作成した. 造影剤は, 原液, 2 倍希釈， 3 倍希釈，4 倍希釈，5倍希釈の濃度の物を用意した。 ファントム内に $20 \mathrm{~cm} / \mathrm{sec}, 30 \mathrm{~cm} / \mathrm{sec}, 40 \mathrm{~cm} / \mathrm{sec}, 50 \mathrm{~cm} / \mathrm{sec}$ の 速度で水を流しながら，各々の造影剂を注入速度 $1 \mathrm{ml} / \mathrm{sec}, 2 \mathrm{ml}$ $\mathrm{sec}, 3 \mathrm{ml} / \mathrm{sec}, 4 \mathrm{ml} / \mathrm{sec}$ で注入し $3 \mathrm{D}-\mathrm{RA}$ を撮影した。 得られた 各画像をワークステーションに転送し，模擬血管ファントム内の信 号值を計測した。【結果】内腔 $4.7 \mathrm{~mm}$ と比べて内腔 $9 \mathrm{~mm}$ では 0.5 〜0.6 倍ほど信号值が低下した。流速が $10 \mathrm{~cm} / \mathrm{sec}$ 上昇することで 0.1〜0.2 倍ほど信号值が度低下した。造影剤注入速度において $1 \mathrm{ml} / \mathrm{sec}$ を基準に $2 \mathrm{ml} / \mathrm{sec}$ では 1.4〜 1.6 倍, $3 \mathrm{ml} / \mathrm{sec}$ では 1.7〜2.1 倍, $4 \mathrm{ml} / \mathrm{sec}$ では 1.9 2.5 倍ほど信号值が上昇した。希釈濃度にお いて, 2 倍希釈で 0.4 倍, 3 倍希釈で 0.5 倍, 4 倍希釈では 0.6 倍, 5 倍希釈では 0.7 倍ほど信号值が低下した。回帰分析により信号值に 影響を与える要因は, 希釈濃度, 内腔, 造影剤注入速度, 流速の順 で小さくなった。【まとめ】頸動脈 3 D-RAに拈ける希釈造影法に おいて, 最適な造影効果を得る上で血流量の影響は考慮する必要が ある。 


\section{技師O2-2}

頝動脈ステント留置術における iFlow 画像の有用性

永寿総合病院 放射線科 11

永寿総合病院 脳神経外科 ${ }^{2)}$

剣持峰範 ${ }^{1)}$ 篠田 純 $^{2)}$ 小野博文 ${ }^{1)}$ 土田靜男 ${ }^{1)}$

Kenmochi Takanori

【目的】頚動脈ステント留置術において, ステント留置前後で iFlow 画像（DSA 撮影画像から造影剂の経時的な血管内移動を力 ラーで表示する）による視覚評価が有用となるか検討した．【方法】 ステント留置前後でCアーム角度, 寝台の高さ, 寝台の位置, FPD の距離, FOV, 造影滆注入速度, 造影滆量が同じになるよう にDSA 撮影を行う. 次に当院で使用している SIEMENS Syngo-XWorkplaceにて Starting（開始時間），Duration（持続時間）を規 格化し iFlow 画像を作成した。 またiFlow 画像にて血管内の ROI を数ヶ所測定し時間対 ROI コントラスト強度グラフを求め相対評 価を行った.【結果】ステント留置後の iFlow 画像では血流量, 血 流速度が増加したことにより造影剂濃度が最大に達するまでの時間 が早くなったためカラースペクトルに大きな変化があった．さらに 自動調節と比べ Starting, Duration を規格化することでコントラ ストが著明に表現でき経時的フォローでも比較できる。また時間対 ROI コントラスト強度グラフからもステント留置後のコントラス トピーク比が高くなった.【結語】同条件で撮影することによりス テント留置前後での視覚評価が可能であり, カラーで表示させるこ とで医師から患者・家族への結果説明の際に有用であると考えられ る.

\section{技師 O2-4}

\section{希釈造影剤を用いた DSA 撮影による頭蓋内ステントの描出に ついて \\ 先端医療センター 放射線技術科 ${ }^{1)}$ \\ 先端医療センター 血管内治療科 ${ }^{2)}$ \\ 神戸市立医療センター中央市民病院 脳神経外科 ${ }^{3)}$}

栗山 巧 ${ }^{1)}$ 谷内 翔 ${ }^{1)}$ 赤松 剛 ${ }^{1)}$ 毛利友里恵 ${ }^{1)}$ 四井哲士 ${ }^{11}$

Kuriyama Takumi

奥内 昇 ${ }^{1)}$ 坂井千秋 ${ }^{2)}$ 坂井信幸 ${ }^{3)}$

【目的】ステントアシスト法を用いた脳動脈瘤コイル塞栓術におい て, DSA 画像からステントの形状を可視化することができるか否 かを目的とする基礎的検討を行った。【方法】血管撮影装置は, SIEMENS 社製 Artis zee BA Twin を使用し, 焦点サイズを large, 撮影フレーム数を $15 \mathrm{~F} / \mathrm{s}, \mathrm{SSD}$ を $90 \mathrm{~cm}$ とした. $20 \mathrm{~cm}$ 厚の水等 価ファントム（以下，ファントム）の中心に, ステントを設置し, DSA を撮影した。希釈造影剤（10\%から $50 \%$ ）を使用し，ステン トの描出に対する画像評価は, imageJ を用いた。【結果と考察】希 釈造影剤は，30\%までステントを描出することができた．しかし， $40 \%$ と $50 \%$ ではステント描出することが困難であった. ステント のコントラスト值は，希釈率が上がることで造影剤のコントラスト 值の標準偏差に入ってしまい，描出が困難であると考える。【結論】 $10 \%$ に希釈した造影剤を使用して DSA 撮影をすることで，ステン トの形状と動脈瘤との関係を簡便に可視化できる事が示唆された. $\mathrm{CBCT}$ の代用として被ばくの低減および手技の簡便さに繋がり，前 治療において反対側にコイル塞栓している動脈瘤がある場合などに 有効であると考える. しかし，焦点サイズを大きくすることで骨の コントラストが明瞭に描出されることが課題であり, 撮影条件やデ ジタル処理について今後の検討課題とする.
技師 $\mathrm{O} 2-3$

頭蓋内ステント留置後の経過観察のための経静脈性 VasoCT の 試み

名古屋第二赤十字病院医療技術部 放射線科 1)

名古屋第二赤十字病院 脳神経外科 ${ }^{2)}$

石川芳信 ${ }^{1)}$ 瀬口繁信 ${ }^{1)}$ 西條貴哉 ${ }^{1)}$ 小島隆生 ${ }^{2)}$

Ishikawa Yoshinobu

【背景および目的】頭蓋内ステント留置後の画像診断による経過観 察は, ステント内血栓症や再狭窄診断のために重要であるが, 現段 階では動脈穿刺によるカテーテル検査での詳細な観察が必要と考え られている. しかし, 外来患者には負担大である為に, 我々はより 低侵襲である経静脈性（intravenous：IV）VasoCTを試みたので, その検査手順と造影剤希釈率を 3 DCT データより検討した. 【IVVasoCT の検査手順】1）IVDSA による Test Injection（TI）法を 利用した頸動脈への造影剂到達タイミングの測定. 2) TI 法によっ て得られた造影剤到達タイミングで本スキャン開始.【方法】1）造 影剤濃度の検討として, 当院で実施された頭部 $3 \mathrm{DCT}$ 症例の内頚 動脈における CT 值を測定し, 希釈率を変えたファントムの CT 值 と比較することで頭蓋内での造影剤の希釈率を推定する．2）同じ く頭部 3 DCT の症例から, 静注された造影剤が頸動脈に到達した 時間を推定することで, TI 法における DSA 撮影回数が最小限とな るように arrival time を設定する.【結果】頭蓋内での造影剤の希 釈率は, 平均 32 倍 (18 - 57 倍). 静注された造影剂が靧動脈に到 達した時間は平均 16.5 秒 $(10-26$ 秒).【まとめ】 IV-VasoCT を 行う時の頭蓋内での造影剤希釈率は, IA に比べて平均 32 倍とかな り希釈されている. DSA 撮影の arrival time（delay time）は 8 秒 以上に設定する，造影剤使用量を減らす為には, 該当患者が事前に 3 DCT を実施している場合は, それから得られた arrival time (delay time) を設定して, 事前の IVDSA を省くことが可能である.

\section{技師 O2-5}

3 D-DSA Fusion image の TS-SS dAVF 治療における有用 性

\section{聖マリアンナ医科大学 横浜市西部病院 ${ }^{1)}$}

庄司善一 ${ }^{1)}$ 小野寺英孝 ${ }^{1)}$ 犬飼 博 $^{1)}$ 榊原陽太郎 ${ }^{1)}$ 中山兼二 ${ }^{1)}$ Shouji Yoshikazu

【目的】硬膜動静脈瘦の安全かつ効果的な治療を行う上で, 画像診 断技術の役割は高い。なかでも横・S 状静脈洞硬膜動静脈瘻（TSSS dAVFs) では, 安易な静脈洞塞栓により, 正常還流路の閉塞や 罹患静脈洞周辺の para-sinus の残存により不完全な治療となる事 が知られている。 これらの問題の解消を目的に 3 D-DSA 画像の Fusion image を用い, 有用であった症例を報告する.【対象】症例 1.77 歳男性 右 TS-SS dAVFs Cognardtype IIa. 症例 2.76 歳男性 左 TS-SS dAVFs, Cognardtype IIa+b 症例 3.66 歳女性 左 TS-SS dAVFs, Cognardtype IIa+b【方法】症例 1. 同側流入動脈よりの 動脈相と正常還流静脈相の画像. 症例 2 . 同側流入動脈よりの動脈 相と静脈洞内に留置したマイクロカテーテル画像. 症例 3 . 対側及 び同側流入動脈よりの動脈相と静脈洞内に留置したマイクロカテー テル画像. 上記のごとく 3 D-DSA 画像を workstation 上で Fusion image を作成した.【使用機器】東芝 infinix Celeve-I, workstation Ziostation【考察・結語】症例 1 では罹患静脈洞と接した正常静脈 洞の分離画像を得た. 症例 2 ではシャントポイントの遠位端の同定 しえた，症例 3 では対側流入動脈から Para-sinus に注ぐ事を確認 し, 留置したマイクロカテーテルのルーメンの確認と適切なワーキ ングアングルの検討を行えた．硬膜動静脈㾇における 3 D-DSA 画 像の Fusion image は, 病態理解を向上させ治療方針・治療戦略に いたるまで有益な方法であった。 
技師 $\mathrm{O} 2-6$

脳動脈瘤の患者が診断・治療・経過観察によって受ける放射線 被ばく線量の評価

名古屋第二赤十字病院医療技術部 放射線科 ${ }^{1)}$

名古屋第二赤十字病院 脳神経外科 ${ }^{2)}$

名古屋大学医学部保健学科 ${ }^{3)}$

瀬口繁信 ${ }^{1)}$ 西條貴哉 ${ }^{1)}$ 石川芳信 ${ }^{1)}$ 小島隆生 ${ }^{2)}$ 小山修司 ${ }^{3)}$

Seguchi Shigenobu

【背景および目的】動脈瘤の患者に対してはその診断ならびに治療 後の経過観察で, CT を中心に様々な画像診断検査が行われる. 特 に脳動脈瘤検索のための頭部 CT angiography (CTA), 頭部血管 撮影 (cerebral angiography : CAG), 治療として脳血管内治療 (interventional neuroradiology : INR) が選択される場合には, 頭 部領域への放射線被ばくが集中する。そこで本研究の目的は, 動脈 瘤の患者の診断, 治療及びその後の経過観察で実施されたX 線画 像診断検查によって受ける脳および水晶体への蓄積吸収線量および 蓄積実効線量を推定することである.【方法】調査の対象となった 症例は 2010 年 1 12 月に動脈瘤の手術を受けた患者 60 例. 未破裂 動脈瘤 26 例 (クリッピング 20 例, INR 6 例), 破裂動脈瘤 34 例 (ク リッピング 23 例, INR 11 例）に対して, 術前診断から術後 2013 年 12 月までの 3 年間での経過観察で実施された頭部に対する X 線 撮影, MR， CT， CTA， CAG, INRの数を調査し，それぞれの 手技における脳, 水晶体に対する臓器線量ならびに実効線量を積算 した.【結果】脳，水晶体おび実効線量に対する 3 年間の平均蓄積 線量は各々 $720 \mathrm{mGy}, 543 \mathrm{mGy}, 23.1 \mathrm{mSv}$, 動脈瘤の状態掞よび術 式別では破裂動脈瘤に対する脳および水晶体線量は未破裂動脈瘤に 比べて高く, クリッピングでは $754 \mathrm{mGy}$ と $597 \mathrm{mGy}$, 塞栓術では $799 \mathrm{mGy}$ と $617 \mathrm{mGy}$ であった。 実効線量は未破裂動脈瘤のクリッ ピングに対して約 $20 \mathrm{mSv}$ ，それ以外は約 $25 \mathrm{mSv}$ とほぼ同等で あった.【まとめ】治療から 3 年間にわたる経過観察によって蓄積 された水晶体線量は $543 \mathrm{mGy}$ であり, 水晶体混濁のしきい線量と なるであろう $0.5 \mathrm{~Gy}$ を超えていた.

\section{技師O2-8}

\section{脳血管内治療における従事者被ばくの考え方について}

公益財団法人老年病研究所附属病院 画像診断部 ${ }^{1)}$

公益財団法人老年病研究所附属病院脳神経外科 2) 公益財団法人老年病研究所附属病院 看護部 ${ }^{3)}$

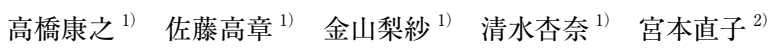
Takahashi Yasuyuki

高玉 真 $^{2)}$ 内藤 功 ${ }^{2)}$ 池田芽衣子 ${ }^{3)}$ 狩野悦子 ${ }^{3)}$ 渡邊マキ ${ }^{3)}$

【背景】平成 26 年 7 月に行われた，「第 11 回日本脳神経血管内治療 学会関東地方会 学術集会」の合同シンポジウム「脳血管内治療に 㧍けるチーム医療」の中で,「血管内治療の手技中，看護師や診療 放射線技師が血管撮影室内に入室している時，医師は撮影や透視を しているか」という話題で，ディスカッションが行われた．その場 で, シンポジストの医師達や，会場の看護師や診療放射線技師の意 見を聞き，施設の方針や個々の考え方に大きな違いがあることがわ かった。【目的】脳血管内治療に携わる, 脳神経外科医師, 手術室 看護師，診療放射線技師にそれぞれアンケートを取り，「当院にお ける脳血管内治療中の従事者被ばくに関する方針」について検討す る.【結果】被ばくに関するアンケート結果から, スタッフの約 8 割は「円滑な手技のため, 撮影も透視も許容できる」とし, 約 2 割 は「できれば撮影や透視をして欲しくないが，必要であれば透視は 許容できる」と回答があった。また，緊急時等では，約 2 割が「気 にせず手技を進めて欲しい」とし，約 8 割が「声をかけて欲しい」 と回答があった.【まとめ】血管内治療中に看護師や放射線技師（以 後,「従事者」とする）が受ける被ばくは低線量被ばくであるため, 放射線による身体的な影響よりも心理的な影響の方が大きいと考え られる.【結語】「当院における脳血管内治療中の従事者被ばくに関 する方針」として，「術者が手技を優先しながらも従事者へ声をか ける事で, 従事者に行動の選択肢を与え, 従事者は手技の妨げにな らないように考えながら業務を遂行する」ことを推奨し，実行・維 持できるようにチーム全体で努めていく.

\section{技師 O2-7}

「脳血管内治療用頭部ファントム」を用いた透視線量と画質の多 施設評価

千葉県がんセンター画像診断部 ${ }^{1)}$

千葉県循環器病センター 放射線科 2)

東京慈恵会医科大学附属病院 放射線科 ${ }^{3)}$

亀田総合病院 放射線科 ${ }^{4)}$

千葉大学医学部附属病院 放射線科 ${ }^{5)}$

NTT 東日本関東病院 放射線科 ${ }^{6)}$

長谷川亮太 ${ }^{1)}$ 今関雅晴 ${ }^{2)}$ 景山貴洋 ${ }^{2)}$ 鈴木宏明 ${ }^{3)}$ 佐藤和彦 ${ }^{4)}$

Hasegawa Ryota

加藤英幸 ${ }^{5)}$ 塚本篤子 ${ }^{6)}$

【目的】第 19 回日本脳神経血管内治療学会で安陪らが報告した頭部 ファントムを用いて，血管撮影装置の透視線量と画質について多施 設調查し，過去の結果と比較することで現状を把握する。【方法】 循環器画像技術研究会および千葉アンギオ技術研究会のうち 19 施 設 24 装置を対象とし，調査期間は 2013 年 11 月より 6 ケ月であっ た。透視線量はスキンドーズモニタを用いてファントムに入射する 線量を測定した。透視条件は, 脳血管内治療で通常使用する条件と し，透視時間は 1 分間である。画質評価はファントム内にX 線テ ストチャートなどの観察物を扱入し，視覚的に評価した。それらの 結果と 2006 年の安陪らの調査結果を比較・検討した。【結果】今回 の結果と安陪らの報告（カッコ内）は, 平均透視線量率が $9.98 \pm$ $4.77 \mathrm{mGy} / \mathrm{min}(22.0 \pm 16.7 \mathrm{mGy} / \mathrm{min})$, 最小一最大透視線量率は $3.48-21.90 \mathrm{mGy} / \mathrm{min}(7.7-65.1 \mathrm{mGy} / \mathrm{min})$ であった。テスト チャートにて視覚的に分解できた周波数の最小ー最大, 中央值は $1.5-5.0,2.5 \mathrm{LP} / \mathrm{mm}(1.5-2.5,2.0 \mathrm{LP} / \mathrm{mm})$ であり, 最新型の 装置のなかには $3.48 \mathrm{mGy} / \mathrm{min}, 4.0 \mathrm{LP} / \mathrm{mm}$ といった低線量・高分 解能の装置も存在した。【考察】平均透視線量率が半減し,ばらつ きも少なくなっていたことから，被ばく低減の取り組みが普及し施 設・装置間の格差が縮小傾向にあると推測できた。さらに今回の調 查施設には「血管撮影・インターベンション専門診療放射線技師」 が在籍しており, 被ばく低減への意識が高いことも要因のひとつと 推測される。本調查では, 透視パルスレート, 検出器視野サイズ, 観察モニ夕が各施設固有であり，実臨床に即した結果を捉える事が できた。今後，各々の影響を考慮した検討を加えたい。

\section{看護01-1}

脳血管撮影検査による大腿動脈穿刺後の安静時間短縮の検討 小倉記念病院 看護部 ${ }^{1)}$

小倉記念病院 薬㨈部 ${ }^{2)}$

小倉記念病院 脳卒中センター 脳神経外科 ${ }^{3)}$

村上真喜 ${ }^{1)}$ 鳥井潤子 ${ }^{1)}$ 隈本伸生 ${ }^{1)}$ 萩原里実 ${ }^{2)}$ 太田剛史 ${ }^{3)}$ Murakami Maki

松本省二 ${ }^{3)}$ 中原一郎 ${ }^{3)}$

【目的】脳血管撮影検査における大腿動脈穿刺後の安静に伴う患者 の苦痛を軽減するために, 安静時間短縮について検討した.【方法】 2013 年 8 月〜 2014 年 6 月に大腿動脈穿刺での脳血管撮影検查後の 安静臥床時間を 2 時間安静と 4 時間安静（以下 $2 \mathrm{H}$ 群・ $4 \mathrm{H}$ 群）に ランダムに振り分けた症例を対象とした. Plt 10 万 $/ \mu 1$ 以下，抗血 小板薬 2 剂以上内服, 抗凝固薬内服, 透析患者, $5 \mathrm{Fr}$ 以上のシー ス使用, 用手圧迫時の血腫形成, 以上に該当した患者は対象外とし た. 検討項目は, 1 . 検査要因 : 検査時間, 用手圧迫時間. 2 . 患者 要因 : BMI, 抗血小板薬の内服の有無. 3 .検査後観察項目 : 穿刺 部合併症の有無, 安静遵守レベル, 意識レベルとした。各項目を $2 \mathrm{H}$ 群と $4 \mathrm{H}$ 群で比較し非劣性を検証した。【結果】対象は 101 名, $2 \mathrm{H}$ 群 44 名 $(42 \%), 4 \mathrm{H}$ 群 57 名（58\%）であった。年齢 $61 \pm 14$ 歳, BMI, 血小板数, 検査時間, 用手圧迫時間, 抗血小板薬内服の 有無, 安静遵守レベル, 意識レベルでは $2 \mathrm{H}$ 群と $4 \mathrm{H}$ 群の間に有意 な差はなく対象のランダム化は正常に行えていた．穿刺部合併症 は, 帰室時では, $2 \mathrm{H}$ 群 $0 \%, 4 \mathrm{H}$ 群 $1.8 \% \quad(\mathrm{p}=0.38), 2$ 時間以内 では, $2 \mathrm{H}$ 群で $2.3 \%, 4 \mathrm{H}$ 群で $1.8 \%$ （ $\mathrm{p}=0.36$.), 12 時間後では, $2 \mathrm{H}$ 群で $2.3 \%, 4 \mathrm{H}$ 群で $5.3 \% （ \mathrm{p}=0.45 ）$ であった。穿刺部合併症 は $2 \mathrm{H}$ 群, $4 \mathrm{H}$ 群の間に有意な差は認めなかった.【結語】 $2 \mathrm{H}$ 群と $4 \mathrm{H}$ 群で大腿動脈穿刺後の出血性合併症の頻度に差はなく, 安全に 4 時間から 2 時間へ安静時間の短縮ができる可能性がある. 


\section{看護01-2}

\section{脳血管内手術施行後の Angio-Seal 使用患者における止血状況} と危険因子の検討

IMS グループ医療法人社団明芳会 横浜新都市脳神経外科病院 ${ }^{1)}$

松館裕子 ${ }^{1)}$ 富樫め〈゙み ${ }^{1)}$ 阿部一弘 ${ }^{1)}$ 重田京子 ${ }^{1)} \quad$ 森本将史 ${ }^{1)}$

Matudate Yuko

【はじめに】当院では，大腿動脈穿刺による脳血管内手術の際，止 血デパイスにアンギオシールを使用している. 今回, 安静時間を最 小限に留め, 患者の苦痛軽減を図る為, アンギオシールハンドブッ ク推奨安静度 (術後安静度ベッド上フリー, ベッドアップ $45^{\circ}$ 可能, 安静解除後起立・歩行可）を取り入れ，圧迫時間を 4 時間で統一し た.このプロトコール実施下に抢ける術後の止血状況と止血困難の 危険要因について検証したのでここに報告する.【対象と方法】対 象は 2014 年 4 月〜 7 月までに大腿動脈より脳血管内手術を受け, アンギオシールにて止血した患者 31 名である. 術後の圧迫解除 4 時間, 安静解除 5 時間で統一し, 解除後, 止血が完全であった患者 と完全でなかった両群患者の諸条件（年齢, 性別, 喫煙, 高血圧, 麻酔, 手術抗凝固薬使用の有無, シースサイズ, 術後 ACT 值) を 比較して $\chi$ 二乗検定を行い，止血困難の原因となる危険因子につい て検討した。【結果・考察】圧迫解除, 安静解除終了後に, 止血が 完全であった患者は 22 名 $(71 \%)$, 止血が不十分で再圧迫が必要で あった患者は 9 名 $(29 \%)$ となった。再圧迫となった危険要因とし て有意差が認められたのは術後 ACT 值であった．大腿穿刺による アンギオシール使用時の術後安静について，ハンドブック推奨安静 度を遵守することで，術後の圧迫解除 4 時間，安静解除 5 時間とい う比較的短時間でも, 効果があることが確認出来た。この検証は患 者の苦痛軽滅に繋がると思われる，今後は，止血困難危険因子とな りうる術後 ACT 時間の対応について検討し, 再圧迫の頻度を減ら していくことで，血管内手術後管理が患者にとってさらに安全で安 楽であるように看護を提供していきたい.

\section{看護01-4}

\section{血管造影室にて全身麻酔で初めて未破裂脳動脈瘤塞栓術を受け} た患者の思い

岡山大学病院 IVR センター1)

\section{岡山大学大学院 脳神経外科 ${ }^{2)}$}

臂香代子 ${ }^{1)}$ 藤澤芳基 ${ }^{1)}$ 野込真由美 ${ }^{1)}$ 眞鍋佳子 ${ }^{1)}$ 祇園由美 ${ }^{1)}$

Hiji Kayoko

菱川朋人 ${ }^{2)}$ 杉生憲志 ${ }^{2)}$ 伊達 勲 ${ }^{2)}$

脳血管内治療に関する看護研究として，局所麻酔下に脳血管内治療 を受けた患者の不安や，開頭手術も含めた未破裂脳動脈瘤に関する 研究はみられるが, 全身麻酔で未破裂脳動脈瘤塞栓術を受ける患者 の不安や思いに焦点を当てた研究は見当たらない．本研究では，血 管造影室にて全身麻酔下で初めて未破裂脳動脈瘤塞栓術を受けた患 者の全身麻酔と未破裂脳動脈瘤塞栓術に対する思いを明らかにする ことを目的とした．全身麻酔下で未破裂脳動脈瘤塞栓術を初めて受 けた患者 5 名に, 研究者が作成したインタビューガイドを用いて, 半構造化面接によるデー夕を収集し質的帰納的に分析した。なお, 本研究は当院看護部倫理審査の承認を得て実施している. その結 果, 未破裂脳動脈瘤塞栓術については,【治療して欲しい】【未破裂 脳動脈瘤があることで感じるやるせなさ】【置かれている状況をあ るがままに受け入れる姿勢】【開頭術による傷跡や剃毛による外見 上の変化と後遺症が残ることへの恐れ】【全面的な医療者への信頼 感】【治療中に脳動脈瘤が破裂したら仕方がない】【治療中の様子を 知ることで沸き起こる漠然とした恐怖】【治療室に入って医療者と 言葉を交わすことで得た安心感】の 8 つのカデリーが抽出され た。全身麻酔については，【治療中の医療者の言動や痛みを感じず に治療を受けたいという願い】【全身麻酔には不安や恐怖がない】 【医療者を信頼してお任せする】【全身麻酔を受けて目が覚めなくて もいい】【麻酔がかかるまでのことははっきり覚えていない】の 5 つのカテゴリーが抽出された，今後は得られた患者の思いを一般化 させ，多くの場面で活用できるよう対象者の数を増やしてさらに検 討を重ねていきたい
看護01-3

脳血管内治療後の安静臥床に伴う腰痛に対する看護介入と患者 の反応

\section{国家公務員共済組合連合会 虎の門病院 ${ }^{11}$}

中島ひろみ ${ }^{1)}$ 柿本裕子 ${ }^{1)}$ 松丸祐司 ${ }^{1)}$

Nakajima Hiromi

【はじめに】当院において脳血管内治療を受ける患者は, 緊急を除 き術前より抗血小板薬 2 剂を服用している．当院では止血デバイス を使用し, さらに穿刺部合併症予防のため術後 6 時間の安静臥床を 行っている．脳血管内治療を受けた患者は ICU に入室し全身管理 を行っているが, ICUでは腰痛への対処方法は標準化されていな い. ICU に勤務する看護師の腰痛に対しての認識が不明で, 現在 各々が行っている介入が腰痛緩和に効果的であるのか疑問を抱い た．そこで，治療後に発生する腰痛に対する看護介入の現状把握 と, 既存の文献から得られた腰痛に効果的とされる看護介入<腰痛 への看護プログラム >を実施し患者の反応を調査した.【目的】 ICU ナースの安静臥床に伴う腰痛に関する知識と認識を明らかに する. ICUに入室する脳血管内治療を受けた患者に対して，＜腰 痛への看護プログラム>を実施し，腰痛の発生状況および看護の効 果を分析する。【方法】ICU 勤務で脳血管内治療後の患者を受け 持った経験があり調査の同意を得られた看護師に対し，腰痛に関す る知識と現在行っている腰痛に対するケアについてアンケート調査 を行った. 2014 年 7 月〜 9 月に脳血管内治療を受け ICU に入室し た患者に対し，既存の文献から得られた腰痛に効果的とされる看護 介入をもとに, 腰痛に対する看護プログラムを作成し, 全ナースが 実施した，帰室後からの腰痛発生時刻の割合と，患者背景（身長, 体重，BMI，性別，年齢，喫煙歴，手術時間を合わせた安静時間， 腰痛の既往）の分析を行った.

\section{看護01-5}

\section{ステント支援下瘤内塞栓術後の患者に対する退院指導の重要性}

\section{一般財団法人広南会広南病院 脳血管内外科 ${ }^{1)}$}

伊藤亜沙美 ${ }^{1)}$ 本郷磨依子 ${ }^{1)}$ 太田祥代 ${ }^{1)}$ 齋藤美奈子 ${ }^{1)}$

Ito Asami

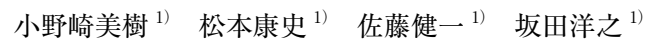

【はじめに】当院ではステント支援下瘤内塞栓術施行後 6 か月間抗 血小板薬を 2 剂内服している。 6 か月以降は 1 剂に減量し， 1 年後 は原則終了としている. 退院後の抗血小板薬副作用出現の割合, 症 状, 及び内服薬減量による副作用を報告する.【目的】ステント支 援下瘤内塞栓術後の抗血小板薬内服による副作用の現状を明確に し，退院指導に役立てる.【方法・対象】2008 2013 年 5 月にステ ント支援下瘤内塞栓を行った患者 110 名中研究対象 67 名. 郵送ア ンケートに返信のあった 50 名を対象とした【結果】入院加療する 重篤な副作用はなかったが, 皮下出血や歯茥からの出血など軽度な 副作用が認められた，抗血小板薬を 2 剂内服中の患者では副作用出

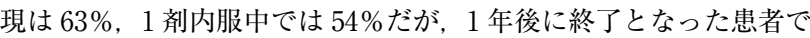
は $16 \%$ で有意に副作用が減少した $(\mathrm{p}=0.0065) 1$ 年間でクロピド グレル（75）内服を終了した患者の副作用出現率は $45 \%, 1$ 年後も 内服を継続した患者では $50 \%$ であり有意はなかった．主な副作用 症状は皮下出血であり，2 剂内服中では $52 \% ， 1$ 郕内服中では $26 \%$ ，内服を終了すると $16 \%$ に減少していた.【考察】手術後穿刺 部異常の報告は多いが, 退院後の抗血小板薬による軽度な副作用の 報告は我々が調べた限りでは無かった。当院の検討では皮下出血が 半数以上に出現し, 内服減量につれ副作用出現率も減り内服に依存 することが明らかになった。【結論】内服中は出血傾向にあること を術前から患者に説明することで不安を軽減し, 副作用対策の指導 をすることは有用である。 


\section{看護01-6}

手術室ナースによるICU ナースへのアンギオ介助指導の推移 レヴィンの場の理論を用いて

国家公務員共済組合連合会 虎の門病院 看護部 手術室 ${ }^{1)}$ 国家公務員共済組合連合会 虎の門病院 脳神経血管内治療科 ${ }^{2)}$ 国家公務員共済組合連合会 虎の門病院 看護部 $\mathrm{ICU}^{3)}$ 中島理恵 ${ }^{1)}$ 成相麻子 ${ }^{1)}$ 中村美也子 ${ }^{1)}$ 松丸祐司 ${ }^{2)}$ 柿本裕子 ${ }^{3)}$ nakajima rie

【はじめに】A 病院では手術室ナースが脳血管撮影などの一部のア ンギオ介助業務を担っているが, 新病院では構造上の理由等でアン ギオ室介助業務全般を ICU ナースが行うこととなった。 新体制に 向けて 2013 年 4 月より ICU ナースに対するアンギオ介助の指導を 開始した．部署を超えての経験年数の豊富なナースへの指導は予測 外の問題が複数生じたので, 問題について文献を用いて整理・考察 した.【方法】ICUナースの手術室兼務の状況を段階的にレヴィン の「推進力」と「抑制力」に分けて開始時と 1 年後とで分析した. 【考察】手術室兼務開始直後, 人も環境も推し進めていく力（推進 力）が不足しており，妨げる力（抑制力）の方が大きかった．抑制 力として予想以上に ICU ナースの被ばくへの恐怖感が強いことや 新しい体制への不満があった，推進力として一部に積極的に手術室 業務を覚えようとするナースがいたが少数であったＩCU ナース は「日勤」で割り当てられたが，業務が午前中で終了する日は担当 するものがなく時間が余り，不満が募った．ICUが忙しい時には ICU ナースは部署のことを心配し，「兼務」という制度に反発心を 覚えていたＩCU・手術室の管理者は意識して，兼務を妨げるもの （抑制力）に対処していった. 放射線技師の勉強会で正しい知識の 周知を行ったり，指導するスタッフを一定の者に限り，業務の状況 に合わせた勤務にするなど対応するなどした，すると，徐々に抑制 力は減少し推進力が増加していった.【おわりに】今回, 推進力と 抑制力の分析を問題に対処した後に行ったが，今後は問題に対処す る前段階でこの分析をすることでより効果的で根拠のあるアプロー チが可能になると考える。

\section{看護01-8}

当院 SCU 看護師の頸動眽ステント術後管理に関する知識につ いて

\section{武蔵野赤十字病院 看護部 11 \\ 武蔵野赤十字病院 薬剤部 ${ }^{2)}$ \\ 武蔵野赤十字病院 脳神経外科 ${ }^{3)}$}

家崎由樹恵 ${ }^{1)}$ 柴本はる菜 ${ }^{1)}$ 川屑聡子 ${ }^{1)}$ 高田亜由子 ${ }^{1)}$

Iesaki Yukie

細谷龍一郎 ${ }^{2)}$ 佐藤洋平 ${ }^{3)}$ 戸根 修 $^{3)}$

【目的】頸動脈ステント留置術（以下 CAS）は頸動脈洞反射や過還 流症候群を引き起こす危険性があり, 異常の早期発見と術後安全管 理においてCAS の専門的な知識が求められる。平成 25 年度に当 院 SCU 看護師にて CAS 術後管理に関するME機器と検査, 薬剤, 随伴症状と合併症知識の実態調査を実施し，カテゴリー間での有意 差が明らかとなった。勉強会開催時期や回数に統一性がない事が影 響したと考えられた為, 今回は各専門家と連携し, 開催時期の設 定・回数の調整をし再度勉強会の効果を明らかにする事を目的とし た.【方法】薬片師・臨床工学士・放射線技師・SCU 看護師による 勉強会実施. CAS 術後管理に必要な問題を作成. SCU 看護師 17 名を対象に質問用紙を配布し同意を得た上で，個人特定されないよ う回答を得た。項目は ME 機器と検査, 薬剂, 随伴症状と合併症 の 3 つのカテゴリーで構成した。質問用紙の項目を点数化し Mann-Whitney 検定を用いて前年度と比較した。【結果】回収率 $100 \%$, 全体正答率 $80 \%$. 昨年から在籍している SCU 看護師 $52.9 \% . \mathrm{SCU}$ 経験年数中央值 2 年で有意差はない. 各カテゴリー別 正答率は ME 機器と検査 $50 \%$ 薬剂 $83.3 \%$ 随伴症状と合併症 $100 \%$ でカテゴリー間での有意差を認めた $(p=0.002)$ ．前年度カテゴリー と群間比較した結果, 薬剤で有意差認めた $(p=0.0032)$.【結論】 薬剂知識が向上したのは SCU 専属薬剤師による講義が影響したと 考える. スタッフの配置転換がある中, 経験年数に有意差がないの は全スタッフ参加を目指し各 2 回ずつ開催した成果と考える. CAS 術後管理において各専門家の協力を得た勉強会開催は効果的 であり, 経験に左右されない看護を提供する基盤作りとなった.

\section{看護01-7}

新人看護職員に対する脳血管撮影看護師業務指導プログラムの 検討

おさか脳神経外科病院 脳神経外科 ${ }^{1)}$

菊池 径 ${ }^{1)}$ 下元昭二 ${ }^{1)}$ 中元勇介 $^{1)}$ 中山恵理子 ${ }^{1)}$ 林 直樹 ${ }^{1)}$

Kikuchi Kei

艼坂直博 ${ }^{1)}$

【研究目的】平成 21 年保健師助産師看護師法において臨床研修が努 力目標とされ，医療機関の機能や規模に関わらず活用できる新人看 護職員研修ガイドラインが作成された。しかし，中小規模の病院で は研修体制の整備に課題がある。当院は脳神経外科及び脳卒中専門 病院で, 脳血管内治療を積極的に行い, 脳血管撮影（以下 DSA と する）も随時行っている．新人看護職員に対するDSA 研修は，お もに文章マニュアルを使用した現場指導を行っているが効果は上 がっていない，そこで，より良い指導プログラムを検討していくに あたり, 新人看護職員の要望や意見を明らかにする所から始めた. 【研究方法】新人看護職員 5 名の聞き取り調査を実施, 得られたデー 夕を分析，検討した。【結果・考察】まず，既存のマニュアルにつ いては,「何時，何をするか記載して欲しい」などの意見が聞かれ た. 次に指導に対しては, 「一連の流れを実際に行いながら教えて ほしい」などの要望が聞かれた，原因として推測できることは，既 存マニュアルの不備による新人看護職員の知識不足や, サポートす る先輩看護師が業務進行を優先してしまい結果的に業務経験が得ら れていないことなどが明らかになった。これらを踏まえ，マニュア ルにDSAの手順画像を載せ, 手順に対する根拠を記載することで, より分かりやすく各手順の理解を深めることに努め, シミュレー ションを取り入れることで，手順一連の流れをより多く経験できる のではないかと考えている．各業務の役割分担を明確にし，新人だ けでなく指導看護師の姿勢も見直し, 段階を踏んだ指導プログラム の構築が必要と考え当院での現在の取り組みについて報告する. 